Manuscript received 25.02.2020

Accepted: 30.03 .2020

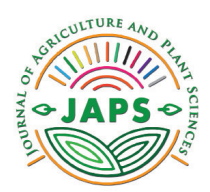

In print: ISSN 2545-4447

On line: ISSN 2545-4455 doi: https:https://doi.org/10.46763/JAPS2010063s Original scientific paper

\title{
THE INFLUENCE OF DIFFERENT CONCENTRATIONS OF PLANT ESSENTIAL OILS ON GROWTH AND REPRODUCTION OF Salmonella enteritidis
}

\author{
Jasmina Stojiljkovic ${ }^{1}$, Metodija Trajchev ${ }^{2}$, Milena Petrovska ${ }^{3}$, Dimitar Nakov ${ }^{2^{*}}$ \\ ${ }^{1}$ Department of Food Technology, College of Applied Studies, Filip Filipovic 20, 17500 Vranje, \\ Republic of Serbia \\ ${ }^{2}$ Department of Animal Biotechnology, Faculty of Agricultural Science and Food, University "St. \\ Cyril and Methodius", Aleksandar Makedonski bb, 1000 Skopje, Republic of North Macedonia \\ 3Department of Microbiology and Parasitology, Faculty of Medicine, University "St. Cyril and \\ Methodius", "50 Divizija" 6, 1000 Skopje, Republic of North Macedonia \\ *Corresponding author: nakovd@fznh.ukim.edu.mk
}

\begin{abstract}
Plant essential oils have been reported to possess antimicrobial properties and therefore have potential usage as natural antimicrobials of food. The aim of the study was to examined the antimicrobial effect of sweet basil and thyme essential oils against growth and reproduction of Salmonella enteritidis reference strain ATCC 13076 (S. enteritidis RS) and Salmonella enteritidis epidemical strain (S. enteritidis ES) cultivated on plate. Therefore, the samples were prepared as a dip application from different concentrations of sweet basil and thyme essential oils (1\%; $2.5 \%$ and $5 \%$ ) with initial concentration of bacteria from $109 \mathrm{CFU} / \mathrm{mL}$ and were cultivated on plate. The control samples were prepared as dip application of bacteria without added essential oils. All samples were exposed at $37^{\circ} \mathrm{C}$ and $46^{\circ} \mathrm{C}$. The growth of $S$. enteritidis RS and S. enteritidis ES was observed only in the control samples without added sweet basil and thyme essential oils. There was not any growth of both Salmonella enteritidis strains in the samples dipped in the 1\%; $2.5 \%$ and $5 \%$ sweet basil and thyme essential oils. The results from the ANOVA indicate that the utilized essential oils in combination with temperature regime was significantly $(p<0.001)$ reduced the CFU number of the both strains of Salmonella enteritidis. These results support the possibility of using sweet basil and thyme essential oil as natural preservatives in food to contribute in the reduction of Salmonella enteritidis at acceptable levels in view to prevent the risk for consumers.
\end{abstract}

Key words: Salmonella, sweet basil, thyme

\section{INTRODUCTION}

Food diseases are caused by consuming foods that have been contaminated by an infectious agent or a toxin produced by it. According to the World Health Organization (WHO), $30 \%$ of people in industrialized countries suffer from foodborne diseases, with at least two million people worldwide in the world died from diarrhea caused by Salmonella (Burt, 2004, Jones, 2011). Salmonellosis prevalence in USA is around 1.3 million cases of foodborne illness, with about 15.000 hospitalizations and 500 deaths per year (Sampathkumar, 2003; Isaacs et al., 2005).
Generally, many foods support the growth of bacteria of the genus Salmonella, but its presence is most commonly associated with raw meat, primarily poultry, eggs, milk, dairy products and non-processed foods (Bajpai et al., 2012; Im et al., 2015). DeKnegt et al. (2015) investigated the appearance of Salmonella serovarants in animals and humans in 24 countries of the European Union in the period 2007-2009 and found out that chicken meat is the main cause of salmonellosis in humans in Europe. Additionally, Salmonella enteritidis in high $95.9 \%$ from foodborne outbreak was 
the main etiological factor for salmonellosis in humans. Ivić-Kolevska and Kocić (2009) have established a trend of increasing the level of food contamination with Salmonella spp. in the Republic of North Macedonia, especially in the period 2006-2007. The most common contaminated food products were mechanically chopped chicken, milk and dairy products, sweets, etc. According to data from other researches made in Serbia, Salmonella enteritidis together with Salmonella typhimurium are considered the most important pathogenic microorganism present in foodstuffs (Karabasil et al., 2013, Rašeta et al., 2014).

Based on the previous researches (Yoshikawa, 1980) it was well established that bacteria from the genus Salmonella have grown on agar with the addition of blood products such as Mac Conkey Agar or Eosin-Methylene blue. Bismuth sulphate agar or deoxycholate agar is used as selective bases for the isolation of bacteria of the genus Salmonella that ferment glucose and mannose, but not lactose or sucrose.

In order to protect food from contamination with pathogens and other harmful microorganisms, including bacteria of the genus Salmonella, many scientists have examined the antifungal, antibacterial and antioxidative properties of plant essential oils and their application in food technology. In several studies (Lachowicz et al., 1998; Shirazi et al., 2014) the antimicrobial activity of the essential oils of Ocimum spp., including the basil was examined, and it was found that the basil essential oil had a mild antimicrobial activity over three Gram positive bacteria
(Lactobacillus plantarum, Listeria monocytogenes, Staphylococcus aureus) and several Gram negative bacteria (Escherichia coli, Pseudmonas aeruginosa, Salmonella thyphimurium, Yersinia enterolitica), yeasts (Rhodotorula) and moulds. Similarly, Ela et al. (1996) determinate the antibacterial and antifungal effect of basil essential oil on Staphylococcus aureus, Escherichia coli and Aspergillus niger. Essential oils were effective to reduce the levels of Salmonella spp. in meat products derived from turkeys (Nair et al., 2014). Also, the antimicrobial activity of essential oils of oregano, thyme, basil, marjoram, lemon grass, ginger and clove, were investigated "in vitro" with method of dilution on agar and there was determined the minimum inhibitory concentration (MIC) against Gram (+) (Staphylococcus aureus and Listeria monocytogenes) and Gram (-) strains (Escherichia coli and Salmonella enteritidis) (Barbosa et al., 2009).

Thyme and orange oils were effective in reducing the concentration of Salmonella enteritidis and Campylobacter coli when culture was inoculated in broths and whole wings (Thanissery and Smith, 2014a).

The aim of the study was to determine the antimicrobial effect of basil and thyme extracts on the growth and reproduction of bacterial cells of two strains of Salmonella spp.: reference test strain Salmonella enterica subsp. enteric serovar Enteritidis (ATCC ${ }^{\circledR} 13076^{\mathrm{TM}}$ ) and Salmonella eteritidis (group D) - epidemic strain, in food isolates, after exposure at $37^{\circ} \mathrm{C}$ and $46^{\circ} \mathrm{C}$ (temperature which correlate with drying procedure of pasta during their production).

\section{MATERIALS AND METHODS}

The test samples were prepared as emulsions of different concentrations of sweet basil and thyme essential oils in physiological solution (PhS) up to final concentration of $1 \%$, $2.5 \%$ and $5 \%$ (micellar solution), and have been inoculated particularly with each of the bacterial strains tested: Salmonella enteritidis reference strain ATCC 13076 (S. enteritidis RS) and Salmonella enteritidis epidemical strain (S. enteritidis ES). The control samples were prepared as dip application of bacteria in physiological solution without added essential oil. Therefore, in order to compare bacterial growth, two types of samples were used: control samples - inoculums of the tested bacterial strains in $\mathrm{PhS}$ and micellar solutions of sweet basil and thyme essential oil that were inoculated with each of the tested bacterial strains.

Fresh sweet basil and thyme essential oil emulsions (Fitofarm, Skopje) were prepared for each phase of the experiment at concentrations of $1 \%, 2.5 \%$ and $5 \%$, which were used as "micellar solutions" for inoculation with bacteria.

All samples were prepared in duplicate. The ready suspension from $S$. enteritidis RS and S. enteritidis ES have been inoculated in $5 \mathrm{~mL}$ of 
the micellar solutions of sweet basil and thyme essential oils (1\%, $2.5 \%$ and $5 \%$ ) as well as $5 \mathrm{~mL}$ of $\mathrm{PhS}$ (control), in initial concentration of bacteria from $109 \mathrm{CFU} / \mathrm{mL}$. In all samples were added 90 $\mathrm{ml}$ Salenit F broth (Merck KGaA, Germany) and subsequently one from the duplicate sample was exposed at a temperature of $46^{\circ} \mathrm{C}$ (pasta drying temperature) for 9 hours, and the other one was exposed at $37^{\circ} \mathrm{C}$ for 18 hours (incubation temperature). Then, the samples were cultivated on plate for enumeration according ISO 6579-1 (2017).

Dilutions 1:20 and 1: 200 were prepared from all samples and from them $0.1 \mathrm{~mL}$ was inoculated on Müller-Hinton agar (Merck KGaA, Germany), for enumeration of bacterial cell count (CFU). Petri plates were incubated at $37^{\circ} \mathrm{C}$ (incubator - Boxun B, Shanghai Boxun Industry and Commerce Co Ltd) for 18 hours (ISO 6579-1, 2017).

Each control and target samples procedure was previously validated in three independent successive experiments, by calculating the mean values used for statistical calculations.

Using one-way analysis of variance (ANOVA) there was tested the statistically significant differences in Log10 number of bacterial cells of S. enteritidis RS and S. enteritidis ES cultured under laboratory conditions depending from the used concentration of the sweet basil and thyme essential oils. For those variables for which the F-value showed statistical significance, a posthoc test was applied (Bonferroni test).

\section{RESULTS AND DISCUSSION}

Table 1 show the results for bacterial cell counts of S. enteritidis RS (Log10) and S. enteritidis ES (Log10) in PhS and micellar solutions with different concentrations of sweet basil and

thyme essential oils in the samples previously exposed at $37^{\circ} \mathrm{C}$ and $46^{\circ} \mathrm{C}$ and incubate at $37^{\circ} \mathrm{C}$ for 18 hours.

Table 1. Number of bacterial cells of S. enteritidis RS (Log10) and S. enteritidis ES (Log10) inoculated in PhS as control and micellar solutions with different concentrations of sweet basil and thyme essential oils.

\begin{tabular}{|c|c|c|c|c|c|c|c|c|c|}
\hline \multirow{2}{*}{ Strain } & \multirow{2}{*}{ Exposure } & \multicolumn{5}{|c|}{ Basil essential oil } & \multicolumn{5}{c|}{ Thyme essential oil } \\
\cline { 3 - 10 } & & Control & $1 \%$ & $2.5 \%$ & $5 \%$ & Control & $1 \%$ & $2.5 \%$ & $5 \%$ \\
\hline \multirow{2}{*}{ S. enteritidis RS } & $37^{\circ} \mathrm{C}$ & 5.53 & 0.00 & 0.00 & 0.00 & 5.51 & 0.00 & 0.00 & 0.00 \\
\cline { 2 - 10 } & $46^{\circ} \mathrm{C}$ & 5.30 & 0.00 & 0.00 & 0.00 & 5.45 & 0.00 & 0.00 & 0.00 \\
\hline \multirow{2}{*}{ S. enteritidis ES } & $37^{\circ} \mathrm{C}$ & 5.51 & 0.00 & 0.00 & 0.00 & 5.51 & 0.00 & 0.00 & 0.00 \\
\cline { 2 - 10 } & $46^{\circ} \mathrm{C}$ & 5.70 & 0.00 & 0.00 & 0.00 & 5.70 & 0.00 & 0.00 & 0.00 \\
\hline \multicolumn{7}{|c|}{$\left(\bar{x}_{ \pm} S_{\bar{x}}\right)$} & $5.51 \pm 0.082$ & \multicolumn{7}{c|}{$5.54 \pm 0.054$} & \multicolumn{1}{c}{} \\
\hline
\end{tabular}

The averages Log10 CFU values for $\mathrm{S}$. enteritidis RS and S. enteritidis ES in control samples, regardless of the exposure temperature, were similar and ranged from 5.30 to 5.70. There wasn't any growth of both Salmonella enteritidis strains in the samples dipped in the 1; 2.5 and $5 \%$ sweet basil and thyme essential oils. Thus, according to the research done by Rattanachaikunsopun \& Phumkhachorn (2010), basil essential oil (Ocimum basilicum) has shown a high antimicrobial effect on Salmonella enteritidis.

Nabrdalik \& Grata (2016) investigated the effect of basil essential oil added at different concentrations $(0.25 \%, 0.5 \%, 1.0 \%, 2.0 \%$ and $4.0 \%)$ on Salmonella enteritidis in a nutrient broth supplemented with $0.05 \%(\mathrm{v} / \mathrm{v})$ Tween 80 (polyethylene sorbitol ester). The initial number of bacterial cells was $10^{8} \mathrm{CFU} / \mathrm{mL}$ (8 $\log \mathrm{CFU} / \mathrm{mL}$ ).
The samples were exposed to a temperature of $37^{\circ} \mathrm{C}$ for $4 \mathrm{~h}, 24 \mathrm{~h}, 48 \mathrm{~h}$ and $168 \mathrm{~h}$. The reduction in the bacterial cell count of Salmonella enteritidis ranged from $3 \%$ to $26 \%$ at $4 \mathrm{~h}$ exposure, to $22 \%$ - $46 \%$ at one-week exposure. In absolute terms, the initial bacterial count of $10^{8} \mathrm{CFU} / \mathrm{mL}$ (8 log CFU / mL) after 24-hour exposure decreased to 6.0287, 5.8783, 5.5903, 5.6037 and $5.6007 \mathrm{log}$ CFU / mL corresponding to the concentrations of basil essential oil used $(0.25 \%, 0.5 \%, 1.0 \%, 2.0$ and $4.0 \%$ ), which was statistically significant at $\mathrm{p}<0.05$.

Further, for example, Boskovic (2016) found a statistically significant decrease in the initial number of bacterial cells from more bacterial species of the genus Salmonella $\left(10^{6}=6 \mathrm{Log}\right.$ $\mathrm{cfu} / \mathrm{g}$ ) inoculated into minced pork with added thyme essential oil in concentrations from $0.3 \%$, $0.6 \%$ and $0.9 \%$. The decrease in the number of 
bacterial cells increased proportionally with the increasing of the essential oil concentration (0.3\%, $0.6 \%$ and $0.9 \%)$.

According to research done by Millezi et al. (2011), the minimum inhibitory concentration of thyme essential oil (T. vulgaris) to $P$. aeruginosa and S. enteritidis, was $5 \%$ and $10 \%$, respectively. According to Thanissery \& Smith (2014b), the combination of $0.5 \%$ thyme and orange essential oils inhibit the growth of Salmonella and Campylobacter bacteria. Even when thyme essential oil was added in much smaller portions
(0.1\%) in chopped lamb packaged in a modified atmosphere, as tested by Karagözlü et al. (2011), an antimicrobial effect was found resulting in a significant extension of the shelf life.

Table 2 shows the statistically significant differences between the number of bacterial cells of S. enteritidis RS and S. enteritidis ES inoculated in $\mathrm{PhS}$ and in micellar solution of basil and thyme essential oil with different concentration, cultivated on nutrient media and exposed at $37^{\circ} \mathrm{C}$ and $46^{\circ} \mathrm{C}$.

Table 2. Statistical differences in Log10 number for CFU/ml of S. enteritidis RS and S. enteritidis ES dipped in different concentration of basil and thyme essential oil and cultivated on nutrient media.

\begin{tabular}{|l|c|c|c|}
\hline \multicolumn{4}{|c|}{ Dependent variable: concentration of basil and thyme essential oil } \\
\hline \multicolumn{1}{|c|}{ Source of variation } & df between groups & df in groups & F-value \\
\hline $\log _{10}$ S. enteritidis RS + basil essential oil & 3 & 4 & $2217.181^{* * *}$ \\
\hline $\log _{10}$ S. enteritidis RS + thyme essential oil & 3 & 4 & $33367.111^{* * *}$ \\
\hline $\log _{10}$ S. enteritidis ES + basil essential oil & 3 & 4 & $3481.000^{* * *}$ \\
\hline $\log _{10}$ S. enteritidis ES + thyme essential oil & 3 & 4 & $3481.000^{* * *}$ \\
\hline
\end{tabular}

${ }^{* * *}$ statistical significance at level $\mathrm{p}<0,001$

The results from the ANOVA indicate that the utilized essential oils in combination with temperature regime was significantly $(p<0.001)$ reduced the CFU number of the both strains of Salmonella enteritidis. The Bonferroni posthoc test showed that there was a statistically significant deference between the control samples compared to target samples in the Log 10 number for CFU/ml of the both strains of Salmonella enteritidis cultivated on nutrient media in laboratory conditions, as is shown in Tab. 3, 4, 5 and 6.

Table 3. Bonferoni test for difference in the Log10 number for CFU/ml of S. enteritidis RS depending from concentration of sweet basil essential oil.

\begin{tabular}{|c|c|c|c|}
\hline $\log _{10}$ S. enteritidis RS + basil essential oil & $1 \%$ & $2,5 \%$ & $5 \%$ \\
\hline Control & $5.41^{*}$ & $5.41^{*}$ & $5.41^{*}$ \\
\hline $1 \%$ & 1 & 0.00 & 0.00 \\
\hline $2,5 \%$ & & 1 & 0.00 \\
\hline
\end{tabular}

*statistical significance at level $\mathrm{p}<0,05$

Table 4. Bonferoni test for difference in the Log10 number for CFU/ml of S. enteritidis RS depending from concentration of thyme essential oil.

\begin{tabular}{|c|c|c|c|}
\hline $\log _{10}$ S. enteritidis RS + thyme essential oil & $1 \%$ & $2,5 \%$ & $5 \%$ \\
\hline Control & $5.48^{*}$ & $5.48^{*}$ & $5.48^{*}$ \\
\hline $1 \%$ & 1 & 0.00 & 0.00 \\
\hline $2,5 \%$ & & 1 & 0.00 \\
\hline
\end{tabular}

${ }^{*}$ statistical significance at level $p<0,05$

Table 5. Bonferoni test for difference in the Log10 number for CFU/ml of S. enteritidis ES depending from concentration of sweet basil essential oil.

\begin{tabular}{|c|c|c|c|}
\hline $\log _{10}$ S. enteritidis ES + basil essential oil & $1 \%$ & $2,5 \%$ & $5 \%$ \\
\hline Control & $5.61^{*}$ & $5.61^{*}$ & $5.61^{*}$ \\
\hline $1 \%$ & 1 & 0.00 & 0.00 \\
\hline $2,5 \%$ & & 1 & 0.00 \\
\hline
\end{tabular}

\footnotetext{
*statistical significance at level $p<0,05$
} 
Table 6. Bonferoni test for difference in the Log10 number for CFU/ml of S. enteritidis ES depending from concentration of thyme essential oil

\begin{tabular}{|c|c|c|c|}
\hline $\log _{10}$ S. enteritidis ES + thyme essential oil & $1 \%$ & $2,5 \%$ & $5 \%$ \\
\hline Control & $5.61^{*}$ & $5.61^{*}$ & $5.61^{*}$ \\
\hline $1 \%$ & 1 & 0.00 & 0.00 \\
\hline $2,5 \%$ & & 1 & 0.00 \\
\hline
\end{tabular}

${ }^{*}$ statistical significance at level $\mathrm{p}<0,05$

A unique statistically significant difference on the level $p<0,05$ in the Log10 number for $\mathrm{CFU} / \mathrm{ml}$ for $\mathrm{S}$. enteritidis RS and $\mathrm{S}$. enteritidis ES was established between controls without addition of basil and thyme extracts and target samples containing basil and thyme essential oil, regardless from the concentration of the oils. In that context, it should be mentioned that a large number of authors were interested in testing the antimicrobial effect of basil and thyme essential oil on pathogenic bacteria in food from animal origin, such as eggs, meat, milk and milk products. All of them revealed that there was an antimicrobial effect on sweet basil and thyme essential oil. The results obtained from the research are in correlation with more literature data related to the examination of the effect of extracts of essential oils.

\section{CONCLUDING REMARKS}

The main reason for the illness of people in the world, caused by food, is the presence of foodborne Salmonella enteritidis. The antifungal, antibacterial and antioxidant capacity of essential oils from plants and their application in production technology reduces the risk of the presence of pathogenic microorganisms in food. The inhibitory effect of basil and thyme essential oils on the growth and reproduction of Salmonella enteritidis in a laboratory experiment that reproduces the conditions of preparation of the pasta, prior to the exposure at a temperature of $46^{\circ} \mathrm{C}$, can be the basis for their use as natural preservatives in food like pasta.

\section{REFERENCES}

Bajpai, V.K., Baek, K-H, \& Kang, S.C. (2012). Control of Salmonella in foods by using essential oils: A review. Food Research International, 45, 722-734.

Barbosa, L.N., Rall, V.L.M., Fernades, A.A.H., Ushimaru, P.L.I., da silva Probst, I., \& Fernandes, A. (2009). Essential oils against foodborne pathogens and spoilage bacteria in minced meat. Foodborne Pathogens and Disease, 6, 725-728.

Bošković, M. (2016) Ispitivanje uticaja odabranih etarskih ulja na rast Salmonella spp. u mesu svinja pakovanog u vacuum i modifikovanu atmosferu. Doktorska disertacija, Fakultet veterinarske medicine, Univerzitet $u$ Beogradu.

Burt, S. (2004). Essential oils: their antibacterial properties and potential applications in foods-a review. International Journal of Food Microbiology, 94, 223- 253.

De Knegt, L.V., Pires, S.M., \& Hald, T. (2015). Attributing foodborne salmonellosis in humans to animal reservoirs in the European Union using a multi-country stochastic model. Epidemiol
Infect. 143(6), 1175-86.

Ela, M.A., El-Shaer, S.N. \& Ghanem, B.N. (1996). Antimicrobial evaluation and chromatographic analysis of some essential and fixed oils. Pharmazie, 51, 993-995.

Im, M.C., Jeong, S.J., Kwon, Y.K., Jeong, O.M., Kang, M.S., \& Lee, Y.J. (2015). Prevalenceand characteristics of Salmonella spp. isolated from commercial layer farms in Korea. Poult Sci, 94, 1691-8.

Isaacs, S., Aramini, J., Ciebin, B., Farrar, J. A., Ahmed, R., Middleton, D., Chandran, A. U., Harris, L. J., Howes, M., Chan, E., Pichette, A. S., Campbell, K., Gupta, A., Lior, L. Y., Pearce, M., Clark, C., Rodgers, F., Jamieson, F., Brophy, I., \& Ellis, A. (2005). An International Outbreak of Salmonellosis Associated with Raw Almonds Contaminated with a Rare Phage Type of Salmonella Enteritidis. Journal of Food Protection, 68, 191-198.

Ivić-Kolevska, S., \& Kocić, B. (2009). Food contamination with salmonella species in the Republic of Macedonia. Foodborne Pathog Dis, 6(5), 627-30. 
ISO 6579-1. (2017). Microbiology of food and animal feedingstuffs - Horizontal method for the detection of Salmonella spp. in the food production chain. Geneva, Switzerland: International Organization for Standardization (ISO).

Jones, F.T. (2011). A review of practical Salmonella control measures in animal feed. J. Appl. Poult. Res. 20, 102-113.

Karabasil, N., Teodorović, V., Dimitrijević, M., Pavlićević, N., Kureljušić, J., Đurić, S., Sočo, I., \& Savić Radovanović, R. (2013). Behavior of Salmonella Typhimurium in pork minced meat and pork skinat different storage temperatures. Acta Veterinaria Beograd, 63, 655-663.

Karagözlü, N., Ergönül, B., \& \zcan, D. (2011). Determination of antimicrobial effect of mint and basil essential oils on survival of E. coli O157:H7 and S. Typhimuriumin fresh-cut lettuce and purslane. Food Control, 22, 1851-1855.

Lachowicz, K.J., Jones, P.G., Briggs, R.D., Bienvenu, E.F., Wan, J., Wilcock, A., \& Coventry, J.M. (1998). The synergistic preservative effects of essential oil of sweet basil (Ocimum basilicum L.) against acid tolerant food microflora. Lett. Appl. Microbiol., 26, 209-214.

Millezi, A.F., Caixeta, D.S., Rossoni, D.F., Cardoso, M.G., \& Piccoli, R.H. (2011). In vitro antimicrobial properties of plant essential oils thymus vulgaris, cymbopogon citratus and laurus nobilis against five important foodborne pathogens. Ciência e Tecnologia de Alimentos Campinas, 32, 167-172.

Nabrdalik, M., \& Grata, K. (2016). Antibacterial activity of Ocimum basilicum L. essential oil against Gram-negative bacteria. Post Fitoterapia, 17, 80-86.

Nair, D.V.T., Nannapaneni, R., Kiess, A., Schilling, W., \& Sharma, C.S. (2014). Reduction of Salmonella on turkey breast cutlets by plant- derived compounds. Foodborne Pathog. Dis., 11, 981-987.

Rattanachikunsopon, P., \& Phumkhachorn, P. (2010). Antimicrobial Activity of Basil (Ocimum basilicum) Oil against Salmonella Enteritidis in Vitro and in Food. Biosci. Biotechnol. Biochem., 74 (6), 1200-1204.

Rašeta, M., Teodorović, V., Bunčić, O., Katić, V., Branković Lazić, I., Polaček, V., \& Vidanović, D. (2014). Antibiotic resistance and molecular studies on Salmonella enterica subspecies enterica serovarlnfantis isolated in human cases and broiler carcasses. Acta Veterinaria Beograd, 64, 257-268.

Sampathkumar, B., Khachatourians, G.C., \& Korber, D.R. (2003). High pH during trisodium phosphate treatment causes membrane damage and destruction of Salmonella enterica serovar Enteritidis. Applied and Environmental Microbiology, 69, 122-129.

Shirazi, M.T., Gholami, H., Kavoosi, G., Rowshan, V., \& Tafsiry, A. (2014). Chemical composition, antioxidant, antimicrobial and cytotoxic activities of Tagetes minuta and Ocimum basilicum essential oils. Food Sci. Nutr. 2, 146-155.

Thanissery, R., \& Smith, D.P. (2014a). Marinade with thyme and orange oils reduces Salmonella Enteritidis and Campylobacter coli on inoculated broiler breast fillets and whole wings. Poult. Sci. 93, 1258-1262.

Thanissery, R., \& Smith, D. P. (2014b). Effect of marinade containing thyme and orange oils on broiler breast fillet and whole wing aerobic bacteria during refrigerated storage. Journal of Applied Poultry Research, 23, 228-232.

Yoshikawa, T.T., Herbert, P., \& Oill, P.A. (1980). Salmonellosis Teaching Conference, HarborUCLA Medical Center, Torrance (Specialty Conference). West J Med. 133, 408-417. 


\title{
ВЛИЈАНИЕ НА РАЗЛИЧНИ КОНЦЕНТРАЦИИ НА ЕКСТРАКТИ НА БОСИЛЕК И ТИМИЈАН ВРЗ РАСТОТ И РАЗМНОЖУВАњЕТО НА Salmonella enteritidis
}

\author{
Јасмина Стојиљковиќ ${ }^{1}$, Методија Трајчев ${ }^{2}$, Милена Петровска ${ }^{3}$ и Димитар Наков ${ }^{2 *}$ \\ 'Институт за технологија на храна, Висока школа на применети студии - Вране, Филип \\ Филиповиќ 20, 17500 врање, Република Србија, \\ 2 Институт за анимална биотехнологија, Факултет за земјоделски науки и храна, \\ Универзитет Св. Кирил и Методиј во Скопје, Бул. Александар Македонски бб, 1000 Скопје, \\ Република Северна Македонија \\ ${ }^{3}$ Институт за микробиологија и паразитологија, Медицински факултет, универзитет Св. \\ Кирил и Методиј во Скопје, "50 Дивизија" 6, 1000 Скопје, Република Северна Македонија \\ "Контакт овтор: nakovd@fznh.ukim.edu.mk
}

\section{Резиме}

Salmonella enteritidis е една од најчестите патогени бактерии кои предизвикуваат заболување кај луѓето преку консумирање храна. Цел на истражувањето беше да се утврди ефектот на екстракти од босилек и тимијан во концентрација од 1\%, 2,5\% и 5\% врз растот и размножувањето во лабораториски услови на два соја Salmonella enteric subsp. enetrica serotype Enteritidis ATCC 13076 референтен сој и Salmonella enteritidis (група D) - епидемиски сој изолиран од храна. Мострите беа експонирани на температури $37^{\circ} \mathrm{C}$ и $46^{\circ} \mathrm{C}$ (температура на која се врши сушење на тестенините во процесот на нивното производство). Растот на двата соја на Salmonella беше утврден единствено во контролниот примерок, без додаток на екстракт од босилек и тимијан. Во примероците со додаток на екстракти од босилек и тимијан, независно од концентрацијата на екстрактот, не беше евидентиран раст на Salmonella enteritidis. Според добиените резултати од статистичката обработка на податоците со користење на ANOVA, екстрактите од босилек и тимијан во сите три испитувани концентрации покажаа високо статистички значајно влијание на ниво $p<0,001$ врз $\log _{10}$ концентрациите на Salmonella enteric subsp. enetrica serotype Enteritidis ATCC 13076 референтен тест сој и Salmonella enteritidis (група D) - епидемиски сој.

Клучни зборови: Salmonella, босилек, тимијан 